Argonne

\title{
Documenting Dual-Column Experiment with Mini-SHINE Solution
}

Chemical Science and Engineering Division 


\begin{abstract}
About Argonne National Laboratory
Argonne is a U.S. Department of Energy laboratory managed by UChicago Argonne, LLC under contract DE-AC02-06CH11357. The Laboratory's main facility is outside Chicago, at 9700 South Cass Avenue, Argonne, Illinois 60439. For information about Argonne and its pioneering science and technology programs, see www.anl.gov.
\end{abstract}

\title{
DOCUMENT AVAILABILITY
}

Online Access: U.S. Department of Energy (DOE) reports produced after 1991 and a growing number of pre-1991 documents are available free via DOE's SciTech Connect (http://www.osti.gov/scitech/)

Reports not in digital format may be purchased by the public from the National Technical Information Service (NTIS):

U.S. Department of Commerce

National Technical Information Service

5301 Shawnee Rd

Alexandra, VA 22312

www.ntis.gov

Phone: (800) 553-NTIS (6847) or (703) 605-6000

Fax: (703) 605-6900

Email: orders@ntis.gov

Reports not in digital format are available to DOE and DOE contractors from the Office of Scientific and Technical Information (OSTI):

U.S. Department of Energy

Office of Scientific and Technical Information

P.O. Box 62

Oak Ridge, TN 37831-0062

www.osti.gov

Phone: (865) 576-8401

Fax: (865) 576-5728

Email: reports@osti.gov

\footnotetext{
Disclaimer

This report was prepared as an account of work sponsored by an agency of the United States Government. Neither the United States Government nor any agency thereof, nor UChicago Argonne, LLC, nor any of their employees or officers, makes any warranty, express or implied, or assumes any legal liability or responsibility for the accuracy, completeness, or usefulness of any information, apparatus, product, or process disclosed, or represents that its use would not infringe privately owned rights. Reference herein to any specific commercial product, process, or service by trade name, trademark, manufacturer, or otherwise, does not necessarily constitute or imply its endorsement, recommendation, or favoring by the United States Government or any agency thereof. The views and opinions of document authors expressed herein do not necessarily state or reflect those of the United States Government or any agency thereof, Argonne National Laboratory, or UChicago Argonne, LLC.
} 


\section{Documenting Dual-Column Experiment with Mini-SHINE Solution}

by

Dominique C. Stepinski, John F. Krebs, Mandy J. Youker, Andrew S. Hebden, and George F. Vandegrift

Chemical Science and Engineering Division, Argonne National Laboratory

prepared for

U.S. Department of Energy, National Nuclear Security Administration, Office of Defense Nuclear Nonproliferation

September 30, 2013 



\section{CONTENTS}

INTRODUCTION ...................................................................................... 1

2 MO-RECOVERY SETUP ............................................................................ 2

2.1 Remote Control of Operations ................................................................ 5

3 CONCENTRATION COLUMN SETUP ......................................................... 8

$4 \quad$ MICRO-SHINE TRACER COLUMN RESULTS ................................................... 12

5 CONCLUSIONS AND FUTURE WORK ......................................................... 14

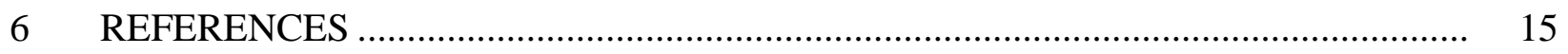

\section{FIGURES}

$1 \quad$ Flow Diagram for the Mo-Recovery Glovebox .................................................. 3

2 Mo-Recovery Glovebox and Equipment Installed per the Flow Diagram

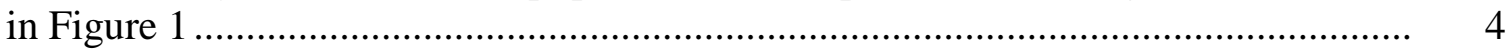

3 Screen Capture of the Data Acquisition and Remote Control Program

Written in the LabVIEW Environment................................................................. 6

4 Screen Capture of the Program Tab That Is Used to Control the Mo-Recovery

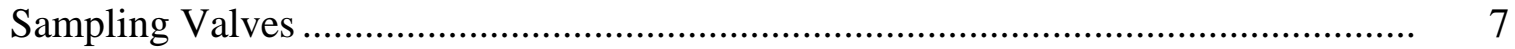

$5 \quad$ Mini-SHINE Concentration Column Setup ................................................... 8

$6 \quad$ Diagram of the Mo-99 Concentration Column Setup ............................................ 10

\section{TABLES}

1 Process Conditions for Mini-SHINE Concentration Column Experiment.................. 9

2 Gamma Counting Results for the Micro-SHINE Tracer Column Experiment............. 13 


\section{DOCUMENTING DUAL-COLUMN EXPERIMENT WITH MINI-SHINE SOLUTION}

\section{INTRODUCTION}

Argonne National Laboratory (Argonne) is assisting SHINE Medical Technologies (SHINE) in developing a production method and recovery and purification processes for molybdenum 99 (Mo-99) using an accelerator-driven, subcritical target consisting of an aqueous uranyl-sulfate solution. An integral part of the process is the development of a column for the separation and recovery of Mo-99, followed by a concentration column to reduce the product volume from 15-25 L to <1 L prior to entry into the low-enriched uranium (LEU)-Modified Cintichem purification process. Argonne has developed plant-scale column designs for the initial Mo-recovery column and the concentration column.

Equipment for the Mo recovery and concentration column has been set up in the Argonne linac facility as part of the mini-SHINE experiment. We completed a column experiment using a linac-irradiated, enriched-uranium-sulfate, micro-SHINE solution as a spike for a depleted uranium (DU) sulfate solution to collect preliminary data for the next stage of the mini-SHINE experiments. 


\section{Mo RECOVERY SETUP}

Two gloveboxes were installed and set up during fiscal year 2013 (FY13) for the miniSHINE project. The first, the target-solution-monitoring glovebox, is described in another report (Youker et al. 2013). The second is the remotely operated Mo-recovery glovebox. This section describes the activities completed in FY13 that led to the installation and testing of the two systems.

Figure 1 is a flow diagram of the Mo-recovery process. Implementation of the flow diagram in the Mo-recovery glovebox is shown in Figure 2. A positive-displacement pump serves the Mo-recovery glovebox and is shared with the target-solution-monitoring glovebox. During Mo recovery, the positive-displacement pump draws the irradiated mini-SHINE target solution from the target vessel. The solution enters the Mo-recovery glovebox through one of the inlet solenoid valves on the left side. The target solution containing the full complement of fission and activation products is then fed onto the heated recovery column from the bottom. The solution is heated to $80^{\circ} \mathrm{C}$ in the lower pre-heater before being introduced onto the column. The column effluent passes through one of the 16-loop trapping flowpath selector (TFS) sampling valves before passing through the pump. After passing through the column, the target solution exits the Mo-recovery glovebox through one of the outlet solenoid valves on the right side as it is directed to the target-solution dump tank that sits beneath the mini-hot cell. After washing the column with a sulfuric acid solution and then water, the Mo-99 is stripped from the column using $0.1 \mathrm{M}$ sodium hydroxide $(\mathrm{NaOH})$. During stripping, the solution is heated to $80^{\circ} \mathrm{C}$ in the upper pre-heater before passing through the heated column from the top. The solution then passes through one of the TFS sampling valves before passing through the pump as it is directed to the Mo-recovery cask that resides outside of the glovebox. Column-washing effluents are captured in plastic bottles that reside in the rear, right side of the glovebox; they are vented to the gas collection system. The wash solutions also pass through the TFS sampling valve, where timed samples are colected before being captured in plastic bottles.

Samples are retrieved from the TFS sampling valves using pre-evacuated vials that are sealed with a septum. The vacuum in the 10-mL vials have been shown to fully draw the solution samples. A miniature vacuum pump was installed in each glovebox. The vacuum pump is vented to the gas collection system. The vacuum pump is used to draw any residual liquid from a sampling valve and to remove droplets from the sample retreival lines. 


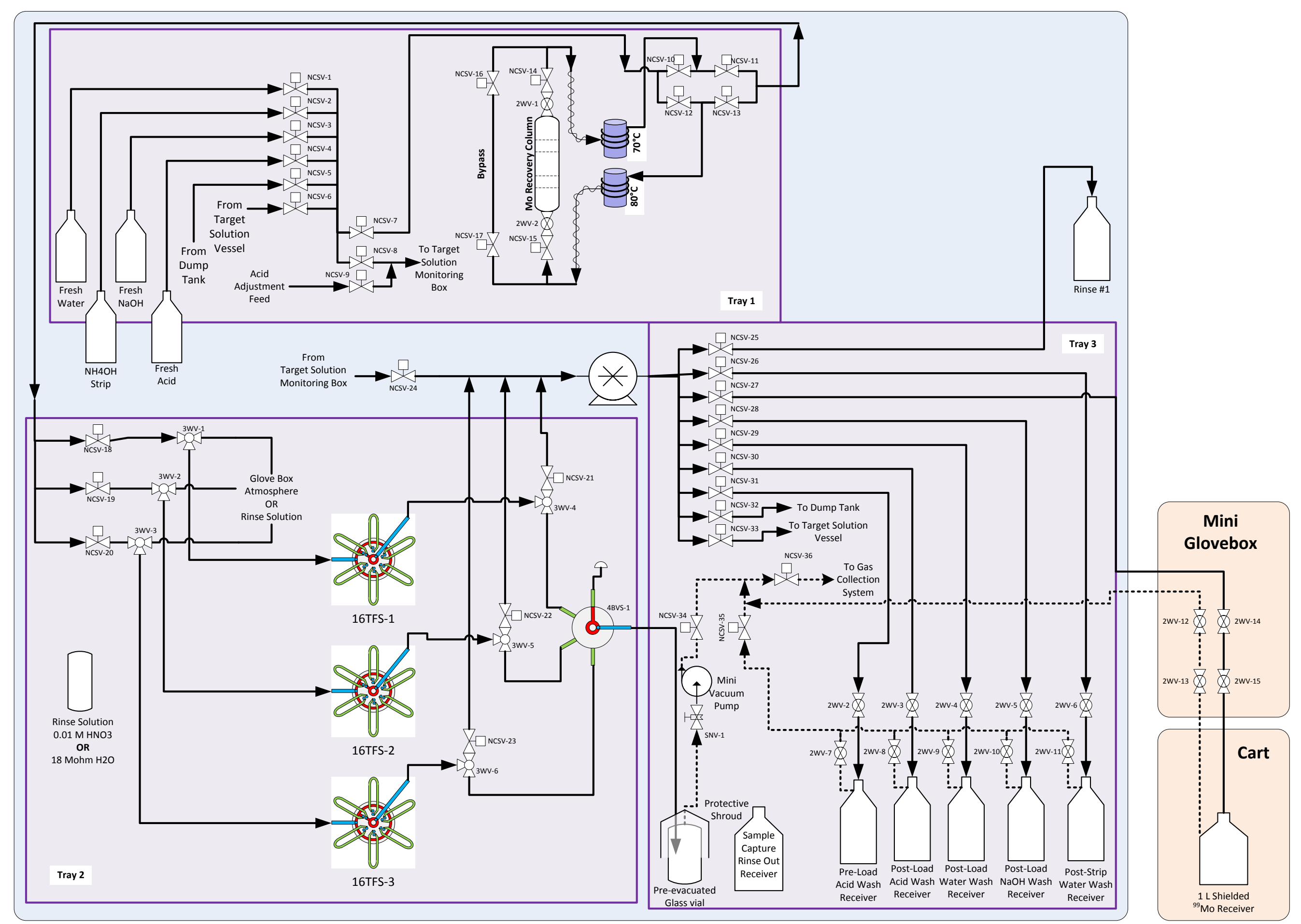

Legend
4-port Manual
Ball Valve
Selector

FIGURE 1 Flow Diagram for the Mo-Recovery Glovebox 

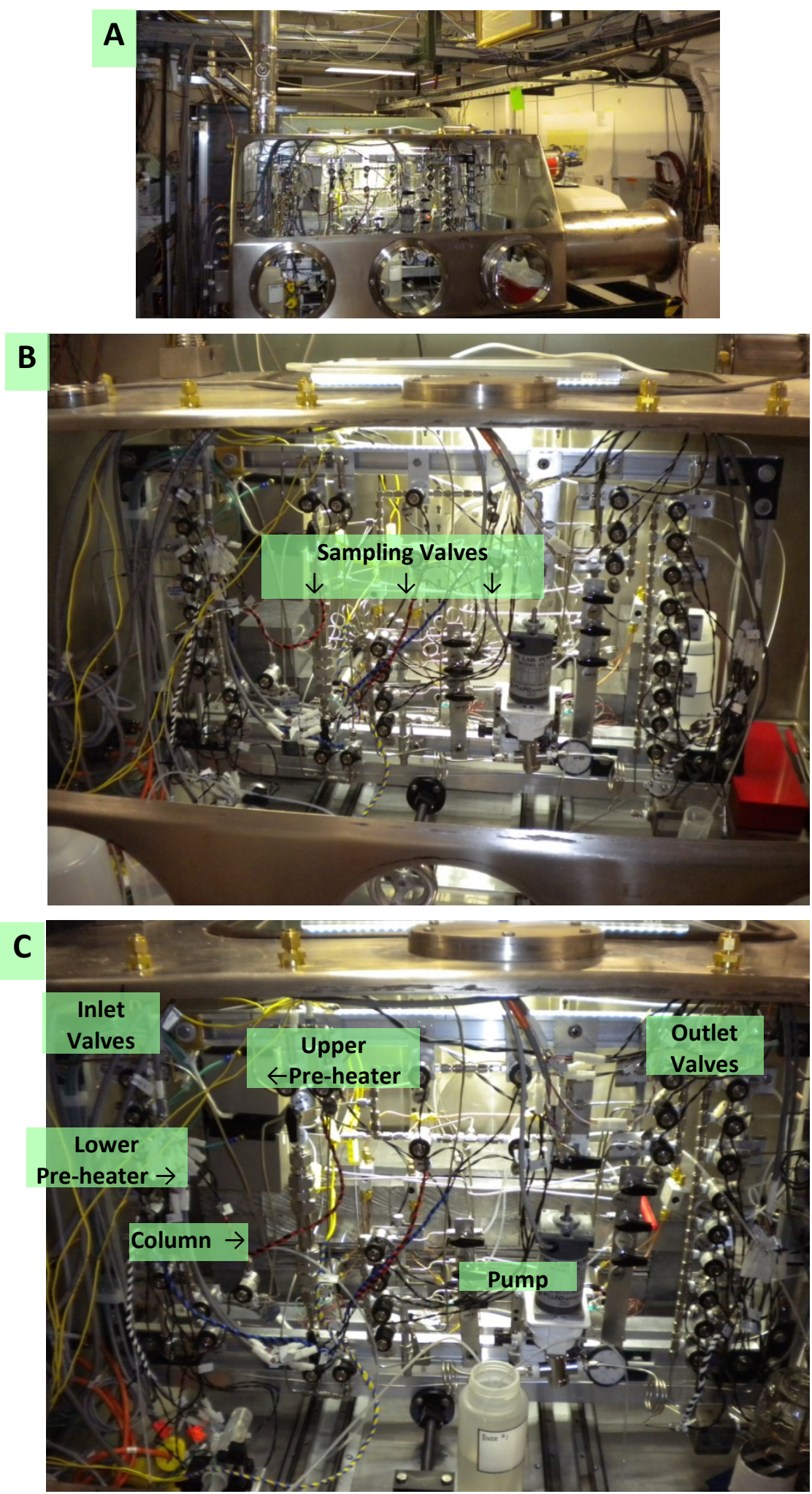

FIGURE 2 (A) Mo-Recovery Glovebox and (B and C) Equipment Installed per the Flow Diagram in Figure 1 (The three 16-loop TFS valves can be seen in $B$.) 


\subsection{REMOTE CONTROL OF OPERATIONS}

A software program was developed that permits operation of the Mo-recovery process remotely. The data-acquisition and remote-control software was implemented in the National Instruments LabVIEW development environment. Programming of the LabVIEW system to remotely control all of the solenoid valves and capture process values began late in the second quarter of FY13. Control of the solenoid valves was accomplished early in the third quarter of FY13. Modifications to the data-acquistion and remote-control program were made during the fourth quarter of FY13.

The system can be operated either in automated or manual mode. In manual mode, a user has full control of all of the liquid solenoid valves and the air-actuated sampling valves. During automated mode, the user simply presses the NEXT STEP button, seen on the right side of Figure 3. With each press of the button, the solenoid valves relevant to the current step in the process are opened and unused valves are closed. The 24 VDC solenoid valves are controlled using quad-format solid-state relays from Measurement Computing Corp. Figure 4 shows the area of the program that is used to control the three sampling valves.

The program captures the temperatures of the upper and lower pre-heaters and the column. The system also records the conductivity, $\mathrm{pH}$, and turbidity values from the targetsolution-monitoring glovebox during solution irradiation. In addition, the program also records the values of the load cells serving the dump tank and the pressure gauges in the gas collection system. All values are time-stamped. To facilitate documentation of an experimental run, several comment boxes are available for users to enter time-stamped comments. 


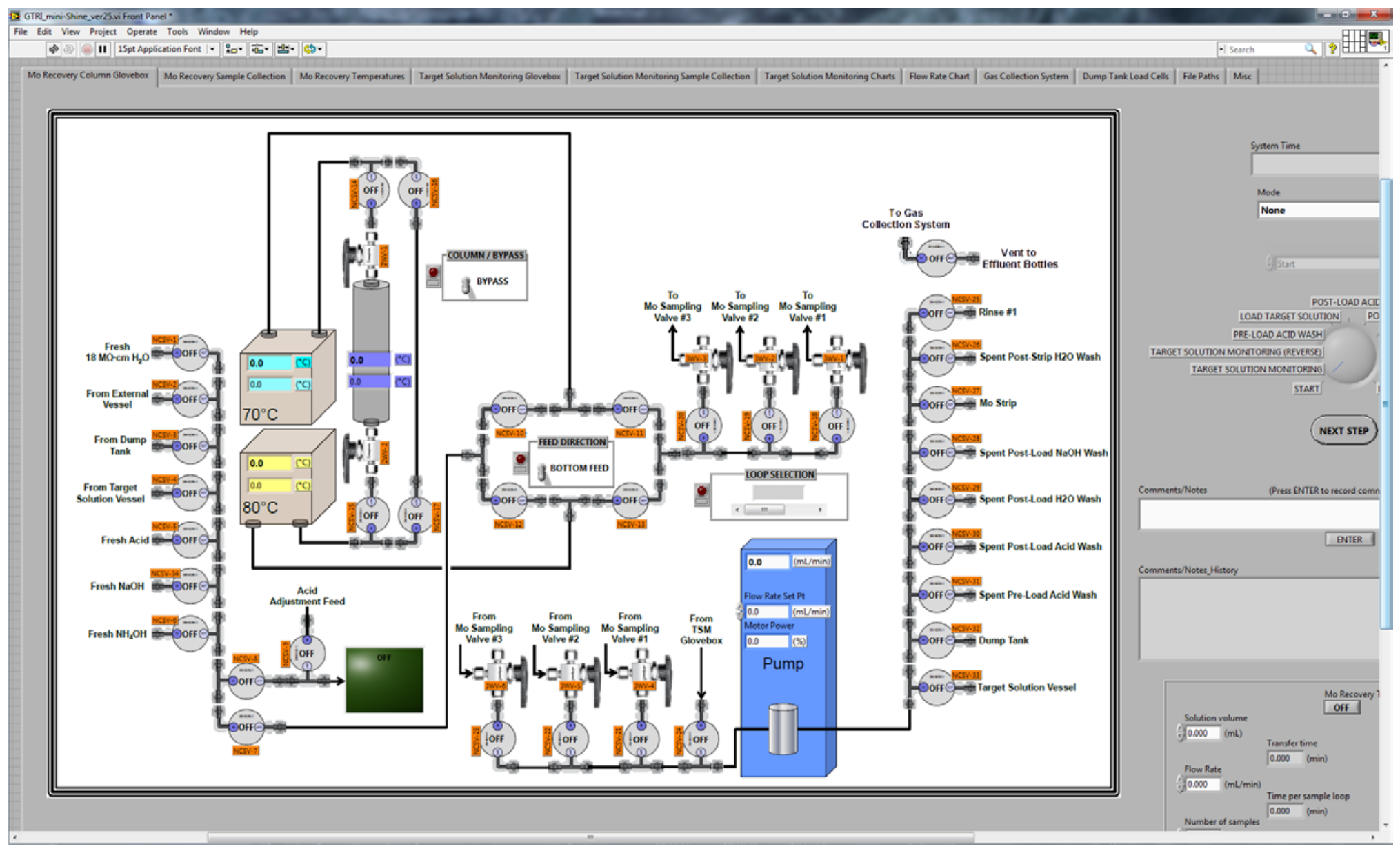

FIGURE 3 Screen Capture of the Data Acquisition and Remote Control Program Written in the LabVIEW Environment 


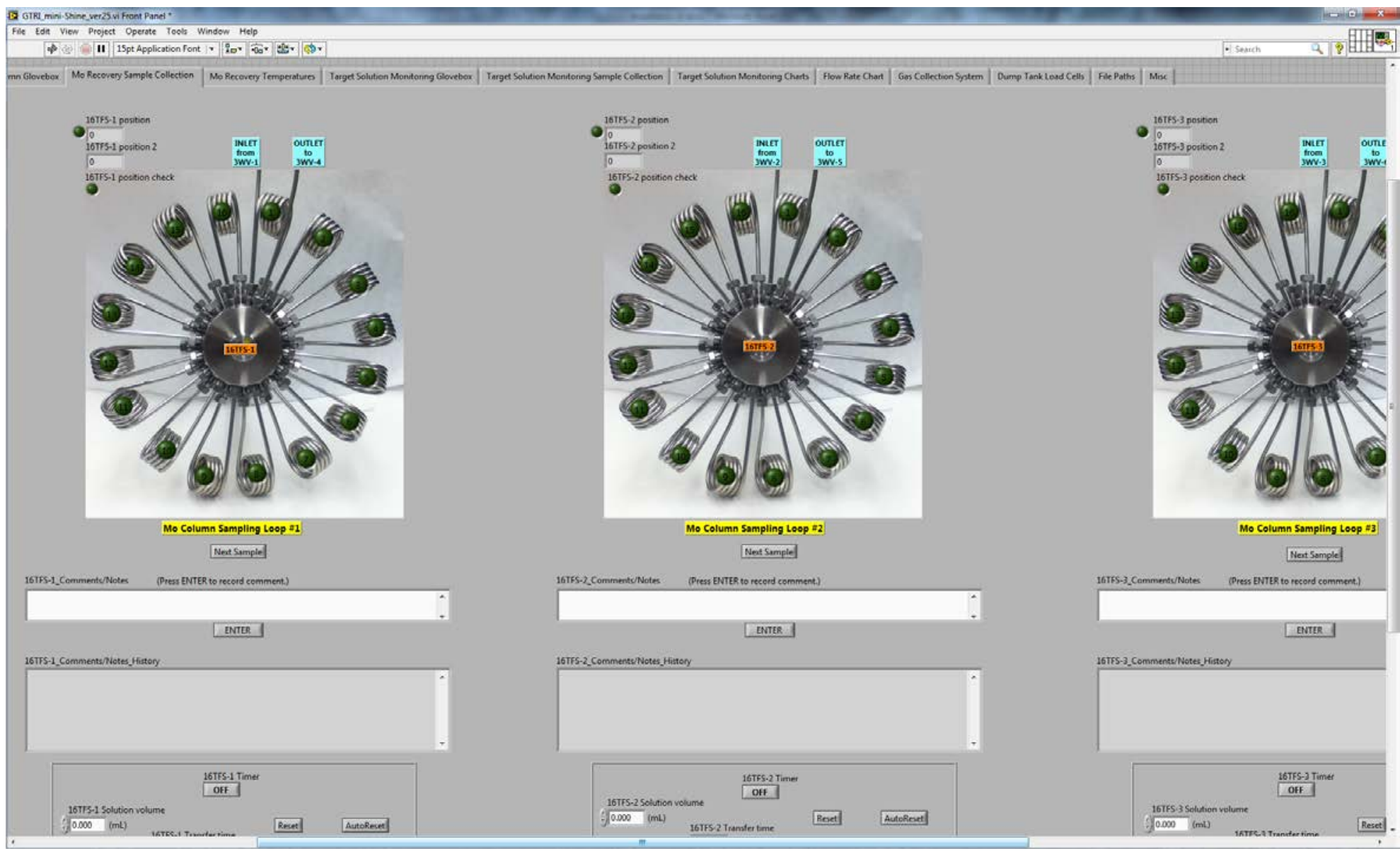

FIGURE 4 Screen Capture of the Program Tab That Is Used to Control the Mo-Recovery Sampling Valves 


\section{CONCENTRATION COLUMN SETUP}

A down-scaled concentration column of the SHINE Mo-99 full scale production column was designed and built for the mini-SHINE experiment (Figure 5). In this process, the Mo-99 strip solution in $0.1 \mathrm{M}$ sodium hydroxide $(\mathrm{NaOH})$ will be acidified to $\mathrm{pH} 2$ and passed through a S40 titania 1-cm inner diameter (I.D.) $\times 1$-cm-long column. The details of the experimental conditions are summarized in Table 1. Mo-99 will be stripped from the concentration column with $24 \mathrm{~mL}$ of $1 \mathrm{M} \mathrm{NH}_{4} \mathrm{OH}$ and then reduced to dryness and acidified to $1 \mathrm{M} \mathrm{HNO}_{3}$ prior to entry into the LEU-Modified Cintichem purification process.

The concentration column experiment will be performed in the linac facility's recently installed shielded box. Figure 6 is a diagram of the concentration column setup. The feed solution containing Mo-99, the wash, and strip solutions will be drawn through a 5-way valve using a positive-displacement pump. The feed and strip solutions will be heated to $80^{\circ} \mathrm{C}$ and $70^{\circ} \mathrm{C}$, respectively, using an inline solution pre-heater. Three-way Swagelok valves and 3-way Hamilton valves will be utilized to enable flow in the up-flow or down-flow direction through the column or the column bypass. The column utilized will be a 10-mm I.D. $\times 100-\mathrm{mm}$ long Benchmark glass column equipped with quick disconnects for easy exchange for subsequent

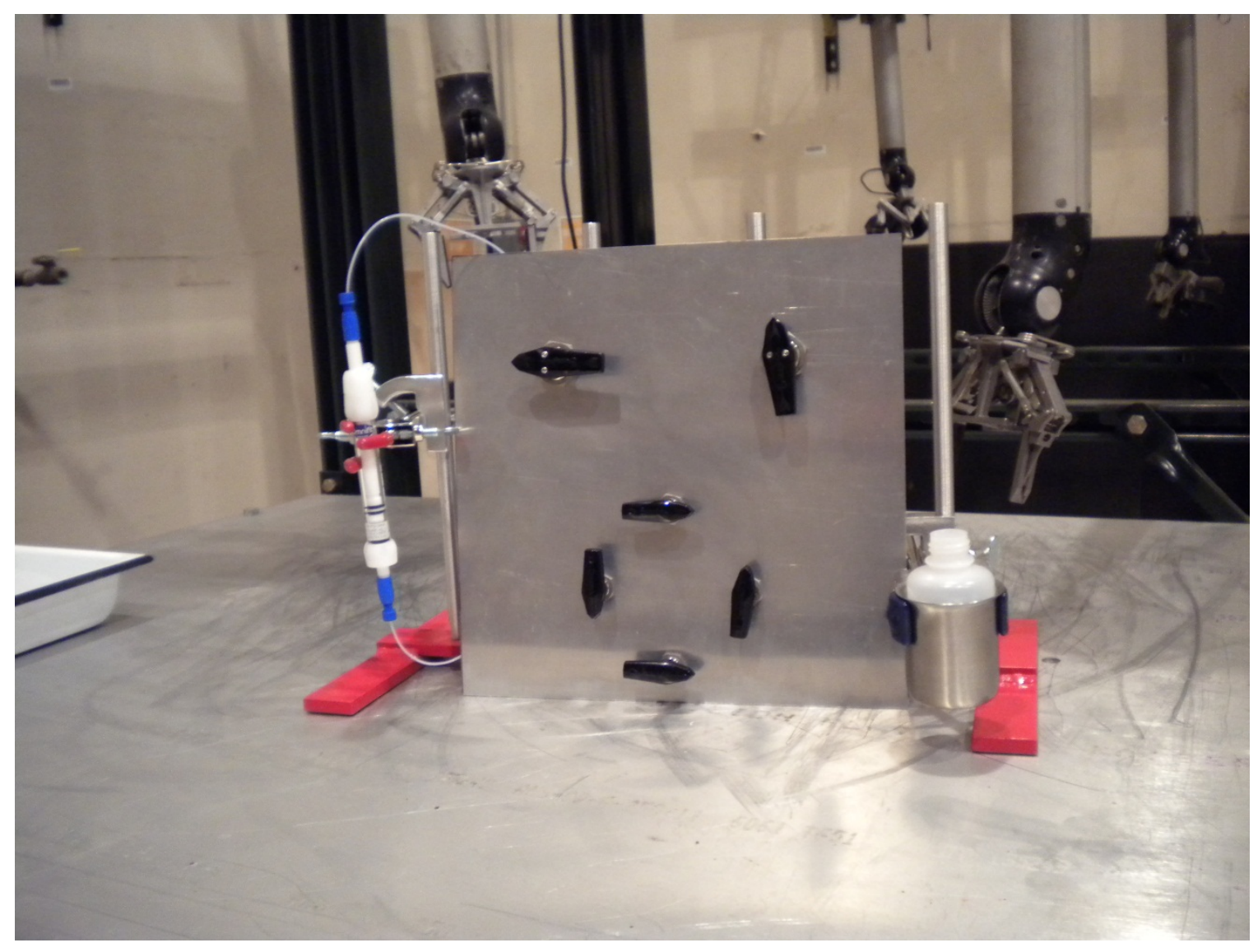

FIGURE 4 Mini-SHINE Concentration Column Setup 
TABLE 1 Process Conditions for Mini-SHINE Concentration Column Experiment

\begin{tabular}{cccccccccc}
\hline Column & $\mathrm{MTZ}_{0.1 \%}$ & $\begin{array}{c}\text { Column } \\
\text { Length } \\
(\mathrm{cm})\end{array}$ & $\begin{array}{c}\text { Column } \\
\text { Volume } \\
(\mathrm{mL})\end{array}$ & $\begin{array}{c}\text { Sorbent } \\
\text { Weight } \\
(\mathrm{g})\end{array}$ & $\begin{array}{c}\text { Velocity } \\
(\mathrm{cm} / \mathrm{min})\end{array}$ & $\begin{array}{c}\text { Flow Rate } \\
(\mathrm{mL} / \mathrm{min})\end{array}$ & $\begin{array}{c}\text { Loading } \\
\text { Time } \\
(\mathrm{min})\end{array}$ & $\begin{array}{c}\text { Solution } \\
\text { Volume } \\
(\mathrm{mL})\end{array}$ & $\begin{array}{c}\text { Strip } \\
\text { Volume } \\
(\mathrm{mL})\end{array}$ \\
\hline & 0.72 & 1.0 & 0.79 & 0.99 & 20.0 & 15.7 & 60 & 941 & 24 \\
\hline
\end{tabular}




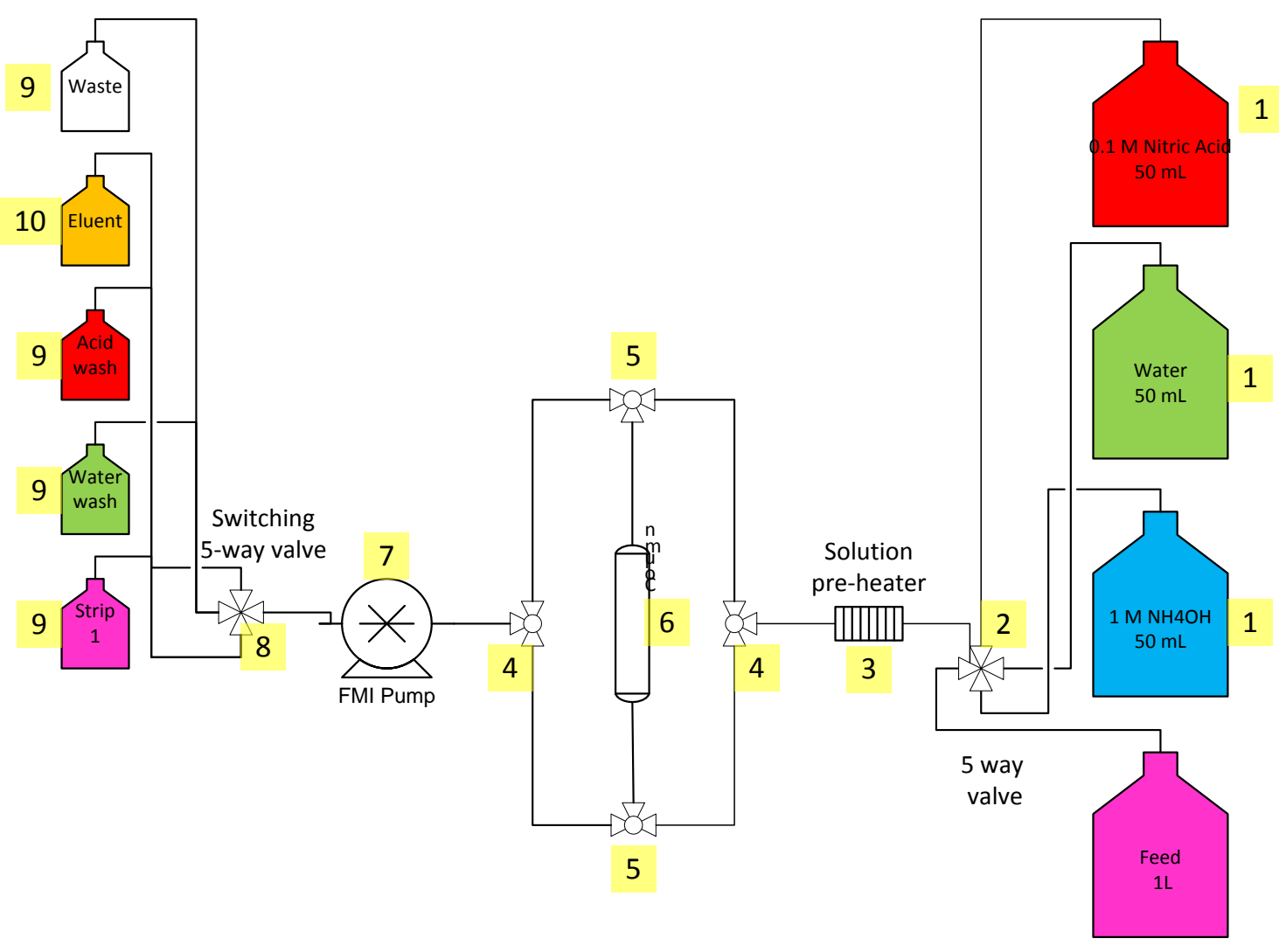

FIGURE 5 Diagram of the Mo-99 Concentration Column Setup

experiments. Column eluent, Mo-99 strip solution, and the washes will be collected, through a 5 -way valve in septa bottles and vented to the gas collection system. Most materials are made of stainless steel (SS), polyether ether ketone (PEEK), polyethylene (PE), or butyl rubber to prevent radiation degradation.

Parts for the concentration column setup include:

1. VWR bottles, high-density polyethylene (HDPE), 4 oz. $\times 3$ beakers, SS, $125 \mathrm{~mL} \times 3$

2. PEEK tubing $1 / 8$ in., .062 in. inner diameter (I.D.), natural (Supleco, 54995) SS tubing, 1/8 in. outer diameter (O.D.) 5-way ball valve, SS, 1/8 in. OD (Swagelok, SS-43ZFS2)

3. Solution pre-heater, $110 \mathrm{VAC} 65 \mathrm{~W} / 350^{\circ} \mathrm{C}$ (VICI HCE1)

4. 3-way 40G ball valve, SS, 1/8 in. O.D. (Swagelok, SS-41GXS2) $\times 2$ 
5. Inert Valve 3 HOUS/3PLUG (Hamilton 8677) $\times 2$

Adapter, SS 1/8-.060 in. (Supleco, 58743) $\times 6$

6. Benchmark column, $10 \mathrm{~mm} / 100 \mathrm{~mm} 1$ x F 1 x A (Omnifit, 006BCC10-10AF) Miniature quick connect, 1/8 in. tube (Swagelok, SS-QM2-B-200) $\times 2$

7. FMI pump

Male connector, SS, 1/8 in. (Swagelok, SS-200-1-2) $\times 2$

8. 5-way ball valve, SS, 1/8 in. O.D. (Swagelok, SS-43ZFS2)

Polytetrafluoroethylen (PTFE) ferrule set for 1/8 in. (Swagelok, T-200-SET)

PEEK tubing 1/8 in., 062 in. I.D., natural (Supleco, 54995)

9. Female connector, SS, 1/8 in. tube (Swagelok, SS-200-7-2) $\times 5$

Luer-to-threaded National Pipe Thread (NPT) connector, male,

LU (Supleco, Z514691) $\times 5$

Syringe needles, SS 304, ST (Sigma-Aldrich Z126756-12EA) × 5

60-mL vials with PP closures and butyl rubber septa

10. Pyrex 1-L bottle, grad, open top cap and butyl rubber septa 


\section{Micro-SHINE TRACER COLUMN RESULTS}

A uranyl-sulfate micro-SHINE solution containing 1 ppm iron sulfate $\left(\mathrm{FeSO}_{4}\right)$ was irradiated on September 3, 2013, and used as a spike for a depleted uranyl-sulfate solution containing $3 \mu \mathrm{M}$ stable $\mathrm{Mo}$, added as sodium molybdate $\left(\mathrm{Na}_{2} \mathrm{MoO}_{4}\right)$. The Mo-recovery operation began 18 hours after the end of the micro-SHINE irradiation. A 0.66-cm I.D. $\times 3-\mathrm{cm}$ long column was packed with a pure titania sorbent made up of $110 \mu \mathrm{m}$ particles with $60 \AA$ pores. Approximately $260 \mathrm{~mL}$ of a uranyl-sulfate solution containing an irradiated micro-SHINE solution ( $2 \mathrm{~mL}$ ) and $3 \mu \mathrm{M}$ stable Mo was passed through the column in 2 hours. After the feed solution was loaded onto the column at a flow rate of $2.2 \mathrm{~mL} / \mathrm{min}$, the column was washed with 10 column volumes (CV) of $0.1 \mathrm{M} \mathrm{H}_{2} \mathrm{SO}_{4}$ and $10 \mathrm{CVs}$ of $\mathrm{H}_{2} \mathrm{O}$ in the up-flow direction. The column and all solutions were heated to $80^{\circ} \mathrm{C}$. Mo was recovered by passing $30 \mathrm{CVs}$ of $0.1 \mathrm{M}$ $\mathrm{NaOH}$ at $1 \mathrm{~mL} / \mathrm{min}$ through the column in the down-flow direction. Table 2 shows the gamma counting results for the fission products that had clean peaks and showed accurate decay patterns over a period of 3 days for the various streams. Gamma counting results were $\pm 5 \%$, and the majority of Mo-99 was recovered in strips 2 and 3, which indicates that less than 30 CVs of $0.1 \mathrm{M} \mathrm{NaOH}$ is required to achieve a high Mo-recovery yield. Mo-recovery is highly dependent on $\mathrm{pH}$, and once the column reaches a $\mathrm{pH}>10$, Mo elutes fairly quickly ( $100 \%$ in $13 \mathrm{CVs}$ ). These data show that less volume is needed for entry into the concentration column operation, which will take less time for entry into the LEU-Modified Cintichem purification process. Previous experiments showed that the Mo product volume would contain 20 to 30 CVs for entry into the concentration column; however, it now appears that 10 to $15 \mathrm{CVs}$ are sufficient. Less feed volume will require a smaller concentration column, which will decrease processing time and allow for quicker entry into the purification process.

It is important to note that these data also indicate that $\mathrm{Mo}(\mathrm{VI})$ has not been reduced to $\mathrm{Mo}(\mathrm{IV})$ or $\mathrm{Mo}(\mathrm{V})$ under the micro-SHINE irradiation conditions, because all Mo adsorbed on the titania column and was easily recovered using $0.1 \mathrm{M} \mathrm{NaOH}$. A significant amount of zirconium (Zr) ( 65\%) remains adsorbed on the column with about half of the iodine, which is consistent with previous tracer tests performed using the same titania sorbent. One surprising result is the fact that tellurium-132 (Te-132) did not adsorb on the titania column, which contradicts previous tracer test results showing that Te adsorbs as well as Mo on the titania sorbent. The irradiation environment may have changed Te's chemistry, thereby removing its ability to adsorb on titania.

The column effluent was then treated with a mixture of barium nitrate $\left(\mathrm{Ba}\left(\mathrm{NO}_{3}\right)_{2}\right)$ and strontium nitrate $\left(\mathrm{Sr}\left(\mathrm{NO}_{3}\right)_{2}\right)$ to convert the uranyl-sulfate solution to a uranyl-nitrate solution. These results are discussed in the report entitled FY-13 Progress Report on the Cleanup of Irradiated $130 \mathrm{~g}$-U/L Uranyl Sulfate SHINE Target Solutions, which was also an end-of-year report.[Bennet] 
TABLE 2 Gamma Counting Results for the Micro-SHINE Tracer Column Experiment

\begin{tabular}{|c|c|c|c|c|c|c|c|c|c|c|c|}
\hline Stream & Sr-91 & Zr-97 & Mo-99 & Ru-103 & Rh-105 & $\mathrm{I}-131$ & Te-132 & $\mathrm{I}-133$ & Ba-140 & Ce-141 & Ce-143 \\
\hline Effluent & 91 & 33 & 0 & 100 & 100 & 29 & 100 & 3 & 100 & 100 & 100 \\
\hline Acid wash & - & 2 & - & - & - & - & - & - & - & - & - \\
\hline Water wash 1 & - & - & - & - & - & - & - & - & - & - & - \\
\hline Strip 1 (1-6 CVs) & - & - & - & - & - & - & - & - & - & - & - \\
\hline Strip 2 (7-14 CVs) & - & 0.2 & 83 & - & - & 4 & - & 17 & - & - & - \\
\hline Strip 3 (15-20 CVs) & - & - & 18 & - & - & 8 & - & 16 & - & - & - \\
\hline Strip 4 (21-30 CVs) & - & - & 2 & - & - & - & - & 11 & - & - & - \\
\hline Water wash 2 & - & - & - & - & - & - & - & - & - & - & - \\
\hline Amount left on column & 9 & 65 & 0 & 0 & 0 & 59 & 0 & 53 & 0 & 0 & 0 \\
\hline
\end{tabular}




\section{CONCLUSIONS AND FUTURE WORK}

Cold testing of the Mo-recovery and concentration column setups is scheduled for the week of October 14, 2013.

The $5 \mathrm{~L}$ of sodium bisulfate $\left(\mathrm{NaHSO}_{4}\right)$ spiked with $100 \mathrm{mCi}$ of Mo-99 will be irradiated the week of October 21, 2013. The solution will be passed through an initial Mo-recovery column, and samples will be collected during irradiation. These steps will be conducted remotely, but sample retrieval will be done manually. The Mo-product solution will be acidified and passed through a concentration column, and the final product from the concentration column will be purified using the LEU-Modified Cintichem process. The concentration column and purification processes will be performed in a hot cell in the linac facility using manipulators.

After the 5-L $\mathrm{NaHSO}_{4}$ experiments are complete, $5 \mathrm{~L}$ of uranyl sulfate (LEU; $19.8 \%$ U-235; $140 \mathrm{~g}-\mathrm{U} / \mathrm{L}$ ) will be irradiated several times for short periods of time to gain an understanding of gas generation rates, $\mathrm{pH}$ changes in solution, and solution volume loss. After several short irradiations have been performed, the $5 \mathrm{~L}$ solution containing $3 \mu \mathrm{M}$ stable Mo, added as $\mathrm{Na}_{2} \mathrm{MoO}_{4}$, will be irradiated for 14 hours, which will produce $2 \mathrm{Ci}$ Mo-99. The solution will be passed through an initial Mo-recovery column (2-cm I.D. $\times 10-\mathrm{cm}$ long) at a flow rate of $40 \mathrm{~mL} / \mathrm{min}$. The solution and column will be heated to $80^{\circ} \mathrm{C}$. The column will be washed with $10 \mathrm{CVs}$ of $0.1 \mathrm{M} \mathrm{H}_{2} \mathrm{SO}_{4}$ and $10 \mathrm{CVs}$ of $\mathrm{H}_{2} \mathrm{O}$. Mo will be recovered using 10 to $15 \mathrm{CVs}$ of $0.1 \mathrm{M} \mathrm{NaOH}$. Samples will be collected remotely during the column process and retrieved manually at least 24 hours post-irradiation. The Mo-product solution will be acidified using nitric acid and passed through a titania concentration column. Mo will be recovered using $1 \mathrm{M} \mathrm{NH}_{4} \mathrm{OH}$ heated to $70^{\circ} \mathrm{C}$. The Mo-product solution will be purified using the LEU-Modified Cintichem process. The final purified product will be shipped to a technetium-99m (Tc-99m) generator manufacturer. The concentration column and purification processes will be performed in a hot cell in the linac facility using manipulators. The $5 \mathrm{~L}$ uranyl-sulfate 14 hour irradiation and subsequent Mo-recovery columns and purification process will be performed at least 4 times. 


\section{REFERENCES}

Bennett, M.E., D. L. Bowers, C. Pereira, A. J. Youker, G. F. Vandegrift, 2013, FY 2013 Progress Report on the Cleanup of Irradiated $130 \mathrm{~g}-U / L$ Uranyl Sulfate SHINE Target Solutions Final, ANL/CSE-13/47, September 27.

Youker, A.J., J. F. Krebs, M. Kalensky, P. Tkac, S. Chemerisov, and G. F. Vandegrift, 2013, FY13 Progress Report on the Phase I Mini-SHINE Water Irradiations and Micro-SHINE Irradiations, ANL/CSE-13/38, September 27.. 
This page intentionally left blank 



\section{Argonne}

Chemical Science and Engineering Division

Argonne National Laboratory

9700 South Cass Avenue, Bldg. 205

Argonne, IL 60439-4837

www.anl.gov 